\title{
PRODUCTIVITY SIMULATION DURING THE PLANNING PHASE OF THE GLENCOE TUNNEL IN CALGARY, CANADA: A CASE STUDY
}

\author{
Hussien T. AL-Battaineh \\ Simaan AbouRizk \\ Department Civil and Environmental Engineering \\ University of Alberta \\ Edmonton, AB, Canada
}

\author{
James Tan \\ Siri Fernando
}

Design and Construction, Drainage Services

City of Edmonton, Alberta, Canada

\begin{abstract}
This paper discusses the Glencoe Storm Sewer Upgrade Project in Calgary, Alberta. The proposed tunnel is $2920 \mathrm{~mm}$ in diameter, stretching along 27th Ave SW from 15th St SW to 20th St SW with a total length of $935 \mathrm{~m}$. Its depth varies from $16 \mathrm{~m}$ at the working shaft to $42 \mathrm{~m}$ at the retrieval shaft. The tunnel will reduce surface flooding by providing temporary storage of stormwater runoff during major storm events. The focus of this paper is project planning. The planning phase includes scope definition, contract setup, cost estimate, team assembly, equipment and material procurements, risk analysis, constructability review, geotechnical investigation, Safety and ECO Plan development, and scheduling and productivity simulations. The challenges presented in this project are the unfamiliarity with the local conditions and the uncertainty of the projected productivity and completion date of the project. Those issues were modeled and mitigation strategies were established using simulation technologies.
\end{abstract}

\section{INTRODUCTION}

The City of Calgary Wastewater Division has engaged the City of Edmonton's Department of Asset Management and Public Works, Drainage Services branch to construct a storm sewer upgrade in the South Calgary Community. The storm sewer upgrade consists of a deep tunnel along 27th Avenue SW from 15th Street SW to west of 20th Street SW. The tunnel will be $935 \mathrm{~m}$ in length with an internal diameter of $2920 \mathrm{~mm}$. The depth varies from $16 \mathrm{~m}$ to $42 \mathrm{~m}$. The tunnel will reduce surface flooding by providing temporary storage of stormwater runoff during major storm events.

Flood protection projects within the City of Calgary are assessed on a points basis and then ranked in order of priority. Points are given for several different categories including public safety, damage caused by flooding, flood frequency, and the cost to benefit ratio for each project. Each year, as funds become available, the highest ranked projects proceed to construction.

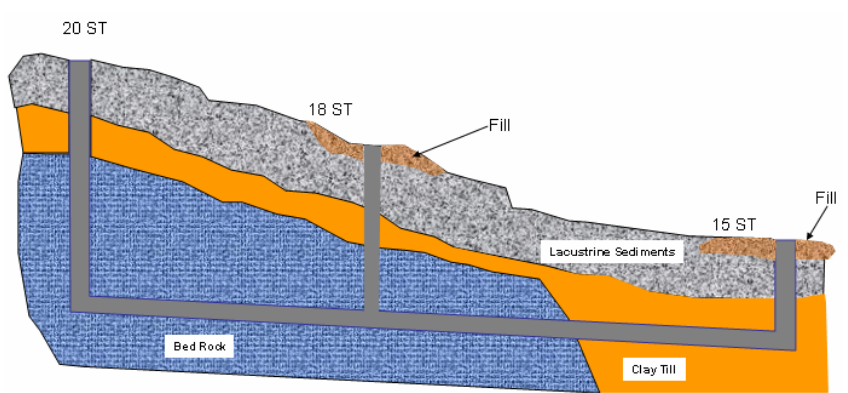

Figure 1: Glencoe tunnel cross-section

The Glencoe Storm Sewer Upgrade had been on hold pending available funds. Funds for the project became available through a program known as ICAP (Infrastructure Canada Alberta Program). ICAP is a co-operative funding program jointly shared between the federal, provincial, and municipal governments. The City assigned an amount of $\$ 62.9$ million to their Wastewater Division to construct a total of 19 stormwater improvement projects in collaboration with ICAP. Glencoe B/C is the last of the Wastewater-ICAP projects to be constructed. The estimated cost for the tunnel portion of the project is $\$ 7.8$ million; the total project cost is estimated at $\$ 11.5$ million. The ICAP assigned a completion date for the project of no later than March 31st, 2006.

An Open House took place on March 23, 2005 to receive comments from the public and to answer questions about the proposed tunnel project. Construction started with the re-location of utilities in late March and early April of 2005. Construction on the tunnel entry shaft got underway in mid-April of 2005.

As shown in Figure 1, the tunnel bores through two types of soil conditions, resulting in three segments: a soft segment represented by clay till, a mixed segment at the transition zone between clay till and bedrock, and a hard segment in the bedrock. The Tunnel Boring Machine (TBM) used in this project is a soft-face machine, which raises the risk either of not being able to tunnel through the bedrock or that the tunneling productivity will be very low. 


\section{CONSTRUCTION SCHEDULE SIMULATION}

The project completion date is a driving factor for this project, and efforts were directed to discuss and create a feasible construction schedule within the given time frame. Several items were discussed including the fact that there are two shafts at the working shaft location and also any benefits that might emerge from connecting the two shafts. Based on these discussions and other research, two parameters were found to have a direct impact on the productivity and schedule: undercut length and the presence or absence of a tail tunnel. The issue of mitigating the high risks involved in working below an existing $900 \mathrm{~mm}$ water main was also discussed .

\subsection{Working Shaft Configuration}

Four construction configurations for the working shafts were discussed in August 2005, during the planning phase of the project:

1- Option A: Constructed by drilling a working shaft and a pump station shaft, and then connecting the two shafts by hand tunneling utilizing two crews (two directions). Once completed, a small undercut $(6 \mathrm{~m})$ as shown in Figure 2 is created. The TBM is then setup and tunneling can commence.

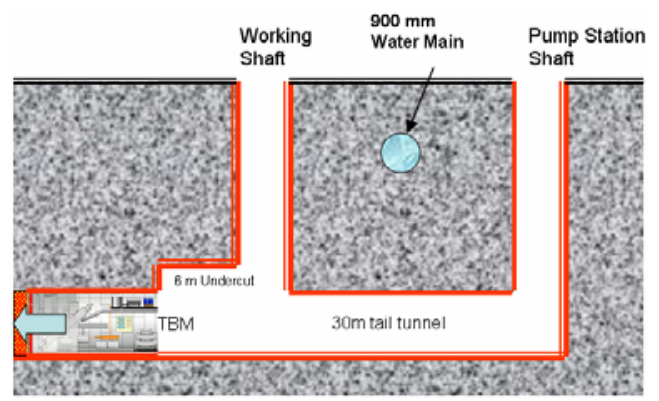

Figure 2: Working shaft configuration option A

2- Option B: This option utilizes an inverted tail tunnel in the direction of the future tunnel, constructing a $30 \mathrm{~m}$ undercut using hand tunneling to avoid working underneath the water main. This is depicted in Figure 3.

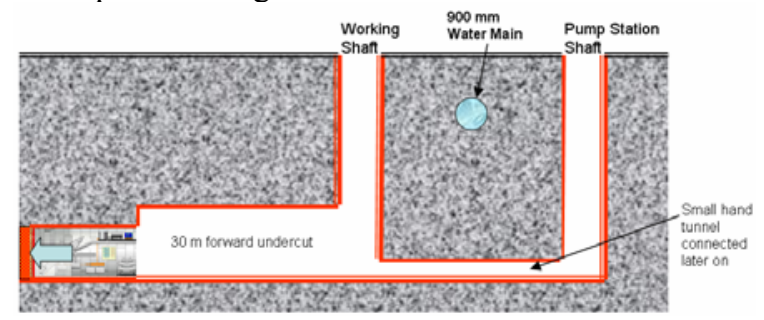

Figure 3: Working Shaft configuration Option B
3- Option C: Constructs a small $12 \mathrm{~m}$ undercut in the direction of the future tunnel, and then starts tunneling using rib and lagging to support the tunnel for the first $30 \mathrm{~m}$. In this case, only one train can be used due to the size of the undercut. This option is shown in Figure 4.

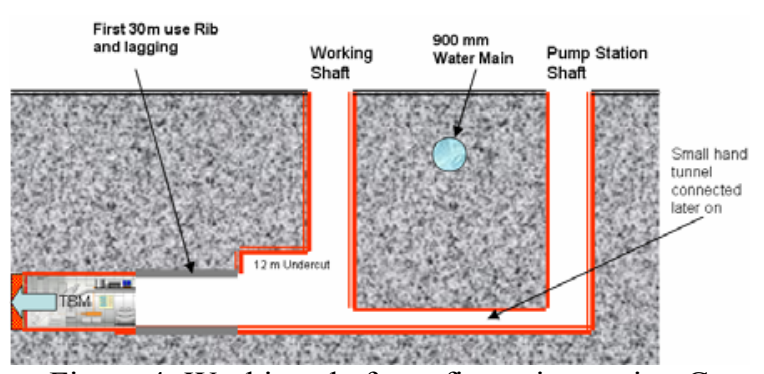

Figure 4: Working shaft configuration option C

4- Option D: Constructs a small $12 \mathrm{~m}$ undercut in the direction of the future tunnel, and then starts tunneling using concrete liners to support the tunnel. Again, in this case, only one train can be used due to the size of the undercut. This option is depicted in Figure 5.

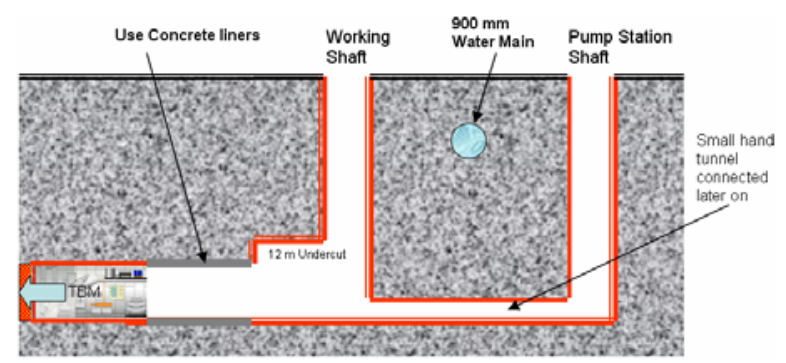

Figure 5: Working shaft configuration option D

\subsection{Construction Simulation}

As show above, four different construction configurations were identified. Furthermore, variable geotechnical conditions are expected to contribute to a high margin of uncertainty. This leads to a need to simulate those scenarios thereby minimizing the associated uncertainty in the decision making process by acquiring more understanding and information about schedule variations. A simulation model has been developed for each of the construction configuration using the Simphony modeling environment.

Simphony is a special purpose simulation environment developed by the construction group at the University of Alberta. The Glencoe project modeled using Simphony is illustrated in Figure 6. 

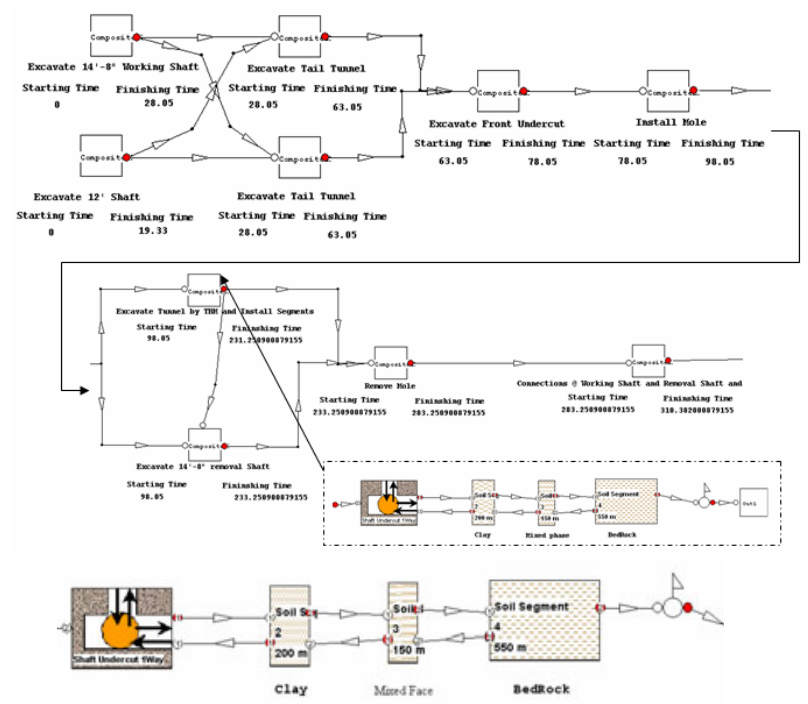

Figure 6: Glencoe simulation model

The purpose of building this model is to determine the schedule milestone dates based on the variable tunneling schema and tunneling parameters. The model then outputs this information in the form of a MS Project file.

\subsection{Schedule Schema}

Eight scenarios were analyzed using the simulation model as shown in Table 7. The variables included: 1) number of hours in each shift; 2) working days per week, and 3) expected penetration rate. The penetration rate included two schemes:

1- Scheme \#1: (Uniform Scheme) TBM penetration rate for the entire tunnel length is the same as in good ground conditions.

2- Scheme \#2: (Variable Scheme) TBM penetration rate depends on geotechnical conditions (see Figure 6).
a. Section \#1: Till clay with a length of 200 meters, assuming good ground condi- tions
b. Section \#2: mixed face with a length of 150 meters, assuming a reduction in TBM penetration rate by $15 \%$.
c. Section \#3: Bedrock with a total length of 550 meters, assuming a reduction in TBM penetration rate by $25 \%$.

\subsection{Construction Scenarios}

Based on the above schemas, six scenarios were developed for the tunnel construction. Those scenarios captured the various working shaft configurations and the expected soil conditions, and are depicted in Table 1:
Table 1: Construction sequence based on variable working shaft configuration

\begin{tabular}{|c|c|}
\hline Option & Description \\
\hline B.1 & $\begin{array}{l}\text { 1. Install the TBM } \\
\text { 2. Construct forward undercut }(30 \mathrm{~m} / @ \text { } \\
1 \mathrm{~m} / \text { day) } \\
\text { 3. Use } 2 \text { trains } \\
\text { 4. The expected soil conditions as in- } \\
\text { dicated }\end{array}$ \\
\hline B. 2 & $\begin{array}{ll}\text { 1. } & \text { Install TBM } \\
\text { 2. } & \text { Construct forward undercut }(30 \mathrm{~m} / @ \text { } \\
& 1 \mathrm{~m} / \text { day) } \\
\text { 3. Use } 2 \text { trains } \\
\text { 4. The expected soil conditions as in- } \\
\text { dicated }\end{array}$ \\
\hline C. 1 & 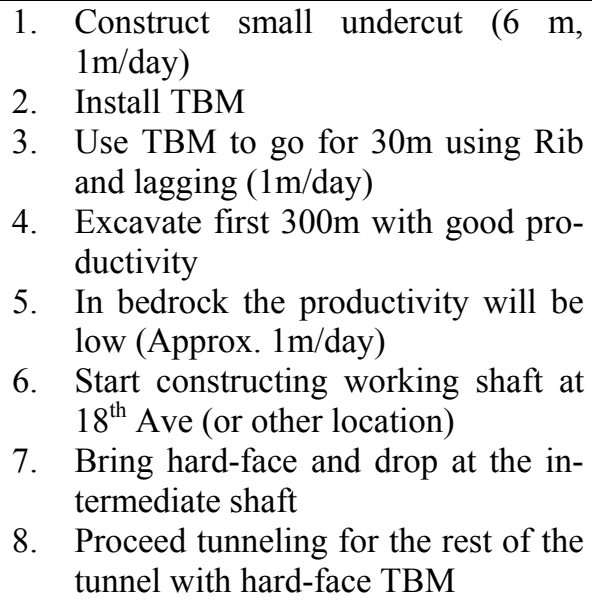 \\
\hline C. 2 & $\begin{array}{l}\text { 1. This option is constructed as follow: } \\
\text { 2. Construct small undercut ( } 6 \mathrm{~m} \text {, } \\
\text { 1m/day) } \\
\text { 3. Install TBM } \\
\text { 4. Use TBM to go for } 30 \mathrm{~m} \text { using Rib } \\
\text { and lagging (1m/day) } \\
\text { 5. Excavate first } 300 \mathrm{~m} \text { with good pro- } \\
\text { ductivity } \\
\text { 6. In bedrock the productivity is found } \\
\text { to be good } \\
\text { 7. Enlarge the first } 30 \mathrm{~m} \text { (rib and lag- } \\
\text { ging section) ( } 30 \text { day) } \\
\text { 8. Proceed tunneling with higher pro- } \\
\text { ductivity }\end{array}$ \\
\hline D. 1 & $\begin{array}{l}\text { 1. Construct small undercut }(6 \mathrm{~m}, \\
\text { 1m/day) } \\
\text { 2. Install TBM } \\
\text { 3. Use Concrete liner } \\
\text { 4. Excavate first } 300 \mathrm{~m} \text { with good pro- } \\
\text { ductivity } \\
\text { 5. When reaching bedrock the produc- } \\
\text { tivity found to be low } \\
\text { 6. Start constructing working shaft at } \\
18^{\text {th }} \text { Ave }\end{array}$ \\
\hline
\end{tabular}




\begin{tabular}{|c|c|}
\hline & $\begin{array}{l}\text { 7. Bring hard face and drop at } 18^{\text {th }} \text { Ave } \\
\text { 8. Proceed tunneling for the rest of the } \\
\text { tunnel }\end{array}$ \\
\hline D.2 & $\begin{array}{ll}\text { 1- } & \text { Construct small undercut }(6 \mathrm{~m}, \\
& 1 \mathrm{~m} / \text { day) } \\
\text { 2- } & \text { Install TBM } \\
\text { 3- } & \text { Use Concrete liner } \\
\text { 4- } & \text { Excavate first } 300 \mathrm{~m} \text { with good pro- } \\
\text { ductivity } \\
\text { 5- }\end{array}$ \\
\hline
\end{tabular}

These scenarios have been modeled in Simphony and were scheduled based on the $10 \mathrm{hr}$ shift, with 6 working days per week. The results are shown in Table 2. The following parameter were evaluated: 1) production rate (m/shift); 2) project duration; 3) completion date, and are outlined in Table 3.

Table 2: Simulation results A

\begin{tabular}{|l|l|l|l|}
\hline Option & \multicolumn{1}{|c|}{$\begin{array}{c}\text { Production Rate } \\
(\mathbf{m} / \mathbf{1 0 h} \text { shift) }\end{array}$} & $\begin{array}{c}\text { Tunnel- } \\
\text { ing Dura- } \\
\text { tion }\end{array}$ & $\begin{array}{c}\text { Total } \\
\text { Dura- } \\
\text { tion }\end{array}$ \\
\hline B.1 & $\begin{array}{l}300 \mathrm{~m} @ 10.5 \mathrm{~m} / \mathrm{shift} \\
600 \mathrm{~m} @ 7.8 \mathrm{~m} / \mathrm{shift}\end{array}$ & 110 days & 150 \\
\hline B.2 & $\begin{array}{l}300 \mathrm{~m} @ 10.2 \mathrm{~m} / \mathrm{shift} \\
600 \mathrm{~m} @ 9.6 \mathrm{~m} / \mathrm{shift}\end{array}$ & 97 days & 127 \\
\hline C.1 & $\begin{array}{l}300 @ 8.1 \mathrm{~m} / \mathrm{shift} \\
100 @ 0.9 \mathrm{~m} / \mathrm{shift} \\
530 @ 7.7 \mathrm{~m} / \mathrm{shift}\end{array}$ & 211 days & 247 \\
\hline C.2 & $\begin{array}{l}300 \mathrm{~m} @ 8.6 \mathrm{~m} / \mathrm{shift} \\
630 \mathrm{~m} @ 11.1 \mathrm{~m} / \mathrm{shift}\end{array}$ & 84 days & 120 \\
\hline D.1 & $300 \mathrm{~m} @ 8.8 \mathrm{~m} / \mathrm{shift}$ & 207 days & 213 \\
& $100 \mathrm{~m} @ 0.9 \mathrm{~m} / \mathrm{shift}$ \\
$530 \mathrm{~m} @ 7.7 \mathrm{~m} / \mathrm{shift}$ & & \\
\hline D.2 & $300 \mathrm{~m} @ 8.6 \mathrm{~m} / \mathrm{shift}$ & 115 days & 121 \\
& $630 \mathrm{~m} @ 8.2 \mathrm{~m} / \mathrm{shift}$ & & \\
\hline
\end{tabular}

Table 3: Simulation results B

\begin{tabular}{|l|l|l|l|l|}
\hline $\begin{array}{l}\text { Op- } \\
\text { tion }\end{array}$ & $\begin{array}{l}\text { \# of } \\
\text { Trains }\end{array}$ & $\begin{array}{l}\text { \# of TBM } \\
\text { machines }\end{array}$ & $\begin{array}{l}\text { Dura- } \\
\text { tion }\end{array}$ & $\begin{array}{l}\text { Completion } \\
\text { Date }\end{array}$ \\
\hline B.1 & 2 & 1 & 217 & $3 / 20 / 06$ \\
\hline B. 2 & 2 & 1 & 204 & $3 / 04 / 06$ \\
\hline C.1 & 1 & 2 & 323 & $7 / 28 / 06$ \\
\hline C.2 2 & 2 & 1 & 197 & $2 / 24 / 06$ \\
\hline D.1 & 1 & 2 & 290 & $6 / 15 / 06$ \\
\hline D.2 2 & 1 & 1 & 198 & $2 / 25 / 06$ \\
\hline
\end{tabular}

As shown in the analysis there is a high risk of being late in the schedule due to the related geotechnical uncertainty. The following two construction scenarios were developed for the purposes of mitigating potential low productivity during the mixed phase.

\subsection{Final Construction Scenario}

Based on the schedule analysis given in the previous sections, it was decided that more information had to be acquired; however, there was a need for this data collection to take place as quickly as possible in order to minimize potential losses. In summary, the following actions were prescribed:

1. Proceed with installing the TBM at $15^{\text {th }}$ street and start tunnelling toward 18 th street.

2. Construct the shaft at 20th Street as soon as possible. Once the shaft is built we will be able to properly acquire the data related to tunneling productivity; that is, we would know the hardness of the rock layer and as such be able to estimate productivity.

3. Based on the findings in Step 2, a decision can be made regarding whether two-way tunnelling is necessary or not. If the $2990 \mathrm{~mm}$ TBM cannot be used in the bedrock or the projected productivity is very low (less than $2 \mathrm{~m} /$ day), then a hard-face TBM would have to be procured and we would commence tunnelling from 20th street toward $18^{\text {th }}$ street, where an extraction shaft would be built. On the other hand, if it is determined that the current $2990 \mathrm{~mm}$ TBM can bore through the bedrock and mixed face with good productivity, then there would be no need to get a new TBM and no need to construct an extraction shaft at $18^{\text {th }}$ street.

Two different scenarios have been identified based on the execution plan and the projected scenarios. Although the schedule is known in general, more analysis was required in order to better understand the uncertainties associated with the main delivery dates. In order to accomplish this, a simulation model has been developed for the two scenarios discussed below:

1. Scenario 1: If the bedrock is found to be suitable for the City TBM, then:

1. Construct undercut $(12 \mathrm{~m}, 1 \mathrm{~m} /$ day $)$;

2. Install TBM;

3. Excavate first $300 \mathrm{~m}$ with good productivity, during which time we will also excavate the extraction shaft at $20^{\text {th }}$ street. A decision must also be reached regarding two-way tunneling ( in this case, there is no need for two-way tunneling);

4. When reaching the mixed face, the productivity is low, yet we proceed through the mixed face.

5. Excavate the last $530 \mathrm{~m}$ in the bedrock with good productivity. 
2. Scenario 2: If the bedrock is determined to be not suitable for the City TBM, then:

a. Construct an undercut (12m, 1m/day);

b. Install TBM at $15^{\text {th }}$ street;

c. Excavate the first $300 \mathrm{~m}$ with good productivity; during that time, we will also excavate the extraction shaft at $20^{\text {th }}$ street. A decision also must be reached regarding two-way tunneling (in this case, two-way tunneling is needed);

d. When reaching bedrock, the productivity is found to be low;

e. Construct working shaft at 20th street;

f. Construct small undercut at the $20^{\text {th }}$ street shaft and drop the second TBM machine;

g. Excavate $530 \mathrm{~m}$ with good productivity towards $18^{\text {th }}$ street;

h. Construct exit shaft at $18^{\text {th }}$ street.

Simulation models have been created for the two scenarios (one-way and two-way tunneling) to decide on the most suitable construction plan. This decision is informed by: 1) shift duration; 2) number of shifts per day; and 3) number of working days per week. This analysis assumes the following:

- Excavation of the $20^{\text {th }}$ street working/removal shaft should start no later than September $1^{\text {st }}$, 2005.

- A decision regarding two-way tunneling will take place after finishing the $20^{\text {th }}$ street shaft.

The anticipated project completion date (March 31, 2006) is not feasible in all of the scenarios (see Table 4). If one assumes that the completion date is the completion of the tunneling process, then only three construction plans can successfully lead to this date in both cases (i.e., one- or two-way tunneling):

- Schedule number 6 and 13: 2 shifts, 8 hrs/shift, 6 working days/week.

- $\quad$ Schedule number 7 and 14: 2 shifts, 10 hrs/shift, 5 working days/week.

- Schedule number 8 and 15: 2 shifts, 10 hrs/shift, 6 working days/week.

\section{ACTUAL PROGRESS AND PROJECT CONTROL}

During the project execution, daily progress data were collected and a project homepage was developed for that purpose. Based on the actual progress, the productivity and penetration rate in the simulation model was updated in or
Table 4: Simulated potential scheduling data

\begin{tabular}{|c|c|c|c|c|c|c|}
\hline \# & 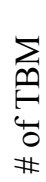 & 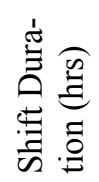 & 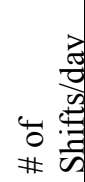 & 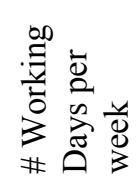 & 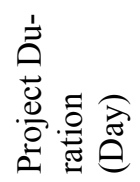 & 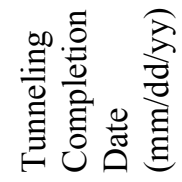 \\
\hline 1 & 1 & 10 & 1 & 5 & 378 & $9 / 8 / 06$ \\
\hline 2 & 1 & 10 & 1 & 6 & 378 & $7 / 5 / 06$ \\
\hline 3 & 1 & 12 & 1 & 5 & 334 & $7 / 5 / 06$ \\
\hline 4 & 1 & 12 & 1 & 6 & 334 & $5 / 11 / 06$ \\
\hline 5 & 1 & 8 & 2 & 5 & 275 & $4 / 18 / 06$ \\
\hline$\overline{6}$ & 1 & 8 & 2 & 6 & 275 & $3 / 6 / 06$ \\
\hline 7 & 1 & 10 & 2 & 5 & 236 & 2/21/06 \\
\hline 8 & 1 & 10 & 2 & 6 & 236 & 1/18/06 \\
\hline 9 & 2 & 10 & 1 & 5 & 307 & $6 / 12 / 06$ \\
\hline 10 & 2 & 10 & 1 & 6 & 310 & $4 / 25 / 06$ \\
\hline 11 & 2 & 12 & $\overline{1}$ & 5 & 286 & $5 / 11 / 06$ \\
\hline 12 & 2 & 8 & 2 & 5 & 275 & $4 / 24 / 06$ \\
\hline 13 & 2 & 8 & 2 & 6 & 279 & $3 / 15 / 06$ \\
\hline 14 & 2 & 10 & 2 & 5 & 265 & $4 / 4 / 06$ \\
\hline 15 & 2 & 10 & 2 & 6 & 269 & $2 / 27 / 06$ \\
\hline
\end{tabular}

der to offer a more realistic projection for the project completion date. Figure 7 shows the productivity analysis conducted on January 24, 2006; based on that update the completion date was projected to be on March 14, 2006. The actual tunnel completion date was March 22, 2006, and the average cumulative productivity around $5.27 \mathrm{~m} / \mathrm{shift}$. The project completion date using the simulation model and the actual project construction schedule shows a good match, with only minimal deviation.

\section{CONSTRUCTABILITY ISSUES}

During the planning phase, the following constructability issues were discussed and resolved either by acting at the time or by having mitigation strategies in place, ready for application:

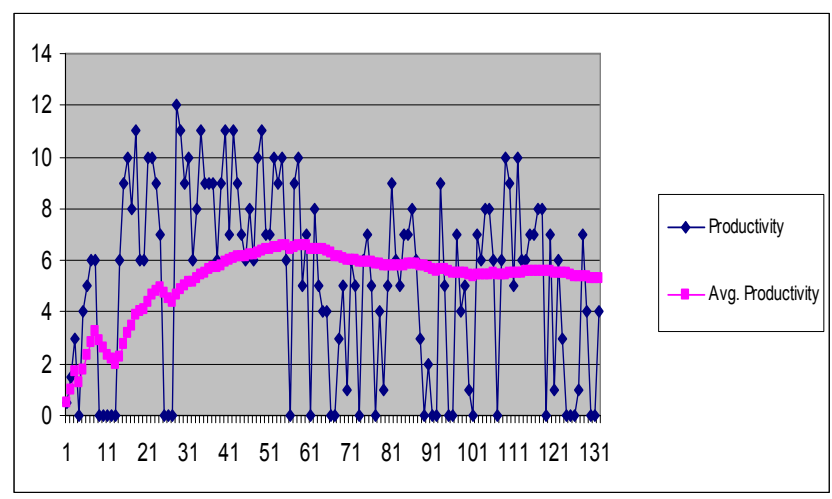

Figure 7: Productivity analysis for Jan. 24, 2006 
1. The working shaft configuration and construction schedule sequence;

2. The production and quality control of concrete liners;

3. Remote job logistics and the need to have good knowledge about local suppliers and services;

4. Spoil removal, storage, and sedimentation control;

5. Manpower and crew rotations in addition to having a suitable place for living, transportation, and insurance of the crews;

6. A stabilized inventory, which included standby parts for items that break often and a backup ventilation system; and increased mobility by means of a new railway, allowing fast delivery direct to Calgary.

\section{CONCLUSION}

This case study shows the importance of the pre-planning stage as a vital foundation for project execution success. The application of risk analysis, constructability reviews, productivity analysis and simulation helped to ensure that the projection of the tunneling completion date and the feasibility of that date remained close. This proximity was reflected in the minimal difference between the model and the actual completion date. Risk analysis helped the project team to identify the high risk factors that could have a negative impact on the project success. Based on this knowledge, several mitigation strategies were developed to deal with those risk factors. Also, during the constructability reviews, important field experience was brought into the discussion, which later helped in identifying a crucial to-do list, the omission of which would have had a direct impact on productivity, cost, and schedule.

The utilization of simulation in this case facilitates an understanding of the project's critical work packages and gives us a tool to identify the main factors influencing productivity. It also demonstrates the flexibility of Simphony as a special purpose simulation environment, highlighting its ability to model several factors, including the impact of the working shaft configuration, geotechnical variation and uncertainty, various process configurations (i.e. one way and two way tunneling), and the resource allocations for both time (shift duration, working day per week) and available crews.

\section{REFERENCES}

TBM Tunnel Simulation Template User's Guide (2000), NSERC/Alberta Construction Industry Research Chair AbouRizk, S., and Mohamed, Y. 2000. "Simphony an integrated environment for construction simulation." In Proceedings of the 2000 Winter Simulation Conference, ed. J. A. Joines, R. R. Barton, K. Kang, and P. A. Fishwick, 1907-1914. San Diego, California: Institute of Electrical and Electronics Engineers.
Hajjar, D., and AbouRizk, S., 1999. "Simphony: an environment for building special purpose construction simulation tools." In Proceedings of the 1999 Winter Simulation Conference, ed. P. A. Farrington, H. B. Nembhard, D. T. Sturrock, and G. W. Evans, 998-1006. Phoenix, Arizona: Institute of Electrical and Electronics Engineers.

\section{AUTHOR BIOGRAPHIES}

HUSSIEN T. AL-BATTAINEH is a Ph.D. candidate in the Department of Civil and Environmental Engineering at the University of Alberta. He received his B.Sc and M.Sc. in Civil Engineering-Structural Engineering from Jordan University of Science and Technology, Jordan in 1997 and 2000, respectively, and an M.Sc. in Construction Management from Western Michigan University in 2002. His research interests are in the application of simulation and optimization in construction management. His email address is <hussien@ualberta.ca>.

SIMAAN M. ABOURIZK is a Professor in the Department of Civil and Environmental Engineering at the University of Alberta. He holds the NSERC/Alberta Construction Industry Research Chair in Construction Engineering and Management, and the Canada Research Chair in Operational Simulation. He received his BSCE and MSCE in Civil Engineering from Georgia Institute of Technology in 1984 and 1985, respectively; and his Ph.D. degree from Purdue University in 1990. His research interests focus on the application of computer methods and simulation techniques to the management of construction projects. His email address is <abourizk@ualberta. ca> and his Web address is

<http: / / www. construction. ualberta.ca/Fa culty/abourizk.shtml>

JAMES TAN graduated with a B.Sc. degree in Civil Engineering from University College London, England in 1980. He emigrated from Malaysia to Edmonton in 1988, and started working with Drainage Services, City of Edmonton in 1989. He is currently the Program Manager of the Expansion Group with the Design \& Construction Section of Drainage Services, overseeing expansion programs which consist mostly of tunneling projects. His email address is $<$ James. Tandedmonton. Ca $>$

SIRI FERNANDO graduated with a B.Sc. (Honours) degree in Civil Engineering from University of Ceylon, Sri Lanka in 1975, and an M. Eng in Construction and Engineering Management from University of Alberta, and hold a Certificate in Project Management from Northern Alberta Institute of Technology. He is currently the Director of the Design \& Construction Section of Drainage Services at the City of Edmonton. His email address is $<$ Siri.Fernando@edmonton.ca $>$ 